DOI: 10.36695/2219-5521.1.2020.78

УДК 341.328

\title{
B.Ф. T€H€ШEB
}

В'ячеслав Фаридович Тєнєшев, викладач Тернопільського національного економічного універсиmemy*

ORCID: 0000-0001-7631-1778

\section{ВПЛИВ ЗБРОЙНИХ КОНФЛІКТІВ НА ДІЮ МІЖНАРОДНИХ ДОГОВОРІВ}

Постановка проблеми. Воєнний конфлікт завжди мав серйозний правовий вплив на міжнародні відносини як сторін конфлікту, так і третіх держав. Що відбувається з договорами, коли спалахує збройний конфлікт? У минулому зазвичай говорили про вплив війни на міжнародні договори. 3 початком воєнних дій для воюючих сторін наступають певні правові наслідки: припинення дипломатичних і консульських відносин; припиняються і забороняються економічні, торговельні, фінансові та інші відносини й угоди 3 юридичними та фізичними особами противника; до громадян ворожої держави може застосовуватися спеціальний режим; оголошення стану війни тягне за собою зміну правового режиму територій тощо. Але в даний час більшість збройних конфліктів не супроводжуються юридичним оголошенням стану війни, але це тим не менше вносить значні зміни в правовідносини сторін. Це стосується і міжнародних договорів.

Війна завжди чинила серйозний вплив на мирні відносини між державами і тим самим - на їх договірні зв'язки. Впливу збройного конфлікту на договори в науковій літературі міжнародно-правового характеру приділялася велика увага. Цього питання торкалися такі відомі вчені-міжнародники, як Я. Броунлі, В. Дурденевский, І. Лукашук, М. Ляхс, А. МакНейр, А. Талалаєв, О. Тіунов, А. Уоттс, Ч. Хайд, К. Харст, О. Мережко, Я. Жукорська та інші. Частина цих досліджень присвячена безпосередньо впливу збройних конфліктів на дію міжнародних договорів, частина - дослідженню дії міжнародних договорів загалом та у зв'язку із збройними конфліктами зокрема.

Питання впливу збройних конфліктів на договори згадувалися в матеріалах кодифікації договірного права, однак так і не отримали закріплення у Віденській конвенції про право міжнародних договорів 1969 року. У 1985 р. було прийнято резолюцію Інституту міжнародного права «Вплив збройних конфліктів на договори». У 2004 р. Комісія міжнародного права ООН включила тему про вплив збройних конфліктів на договори в програму своєї роботи, за результатами якої в 2011 р. Комісія прийняла звід із 18 проєктів статей і додаток $з$ коментарями на цю тему1.

Метою статті є розгляд питання впливу збройних конфліктів на дію міжнародних договорів в умовах сучасного міжнародно-правового регулювання.

Виклад основного матеріалу. Тривалий час існував принцип, що війна між державами веде до припинення всіх договорів між ними. Зокрема, Е. де Ватель писав, що «договори передбачають стан миру»². Проте згодом це положення змінилося.

У науці міжнародного права висловлюються різні точки зору на характер наслідків війни на дію міжнародних договорів. Зокрема, Ч. Хайд відповідь на питання, чи зберігає або втрачає дію договір внаслідок війни, виводив $з$ намірів сторін договору під час його укладання ${ }^{2}$ O.І. Тіунов вважав, що це питання «має вирішуватися не на основі встановлення «намірів» сторін у момент укладення угоди, а з урахуванням їх відповідного волевиявлення після початку війни», обгрунтовуючи це тим, що «війна не може автоматично припинити дію угоди» 4 .

Слід звернути увагу й на відсутність суворої послідовності з цього питання і в практиці міжнародних відносин. Це стало однією з причин відсутності відповідних положень в Віденській конвенції про право міжнародних договорів. У ст. 73 Конвенції 1969 р. акцентується, що «положення цієї Конвенції не вирішують наперед ні одного 3 питань, які можуть виникнути щодо договору <.. > 3 початку воєнних дій між державами»5

Незважаючи на наведене положення, низка загальних положень Віденської конвенції може служити підставою для вирішення деяких 3 цих питань:

- порушення договору однією зі сторін (ст. 60) - істотне порушення двостороннього договору одним із його учасників дає право другому учасникові посилатись на це порушення як на підставу для припинення договору або призупинення його дії в цілому або в частині. Агресія означає істотне порушення багатьох договорів і дає стороні, що зазнала нападу, право припинити або призупинити їх дію. Водночас цього права позбавлений агресор, оскільки Конвенція 1969 р. встановила неприпустимість посилання на неможливість виконання або на зміну обставин, якщо вони стали результатом невиконання цим учасником своїх зобов'язань;

- неможливість виконання (ст. 61) - збройний конфлікт робить неможливим виконання багатьох договорів між учасниками. Щодо одних договорів неможливість носить тимчасовий характер - такі договори призупиняють дію; щодо інших договорів неможливість виконання носить незворотній характер - вони припиняються;

(C) В.Ф. Тєнєшев, 2020

*Vyacheslav Tienieshev, Lecturer of Ternopil National Economic University 
- докорінна зміна обставин (ст. 62) - безумовно, збройний конфлікт вносить у взаємовідносини сторін достатньо серйозні зміни для того, щоб бути підставою припинення або призупинення дії договорів між ними.

Нині збройний конфлікт сам по собі не означає припинення всіх двосторонніх договорів. Рішення залежить від учасників конфлікту. Війна розриває договори політичного характеру, несумісні 3 конфліктом. Неполітичні договори у своїй масі призупиняють свою дію. Це положення підтверджується, зокрема, й сучасною українською договірною практикою. Багатосторонні договори, що встановлюють загальні норми міжнародного права, зберігають значення; багатосторонні договори, які є установчими актами міжнародних організацій, зберігають чинність, але можуть мати обмеження, пов’язані з військовими діями ${ }^{6}$.

Певну визначеність у розуміння змісту існуючих звичаєвих норм та напрямів прогресивного розвитку норм міжнародного права дають статті Комісії міжнародного права ООН про наслідки збройних конфліктів для міжнародних договорів (далі - Статті) ${ }^{7}$.

Звертає на себе увагу термінологія, що використовується в Статтях.

По-перше, ст. 1 закріплює, що Статті «застосовуються до наслідків збройного конфлікту для договірних відносин між державами». Це формулювання свідчить про те, що Статті не обмежують предмет свого регулювання лише відносинами між державами-сторонами збройного конфлікту, а також охоплюють позицію держав-сторін договору, які не є сторонами збройного конфлікту, стосовно держави, яка бере участь у збройному конфлікті.

По-друге, якщо термін «міжнародний договір» використаний з традиційним, характерним для Віденських конвенцій з права договорів змістом, то щодо розуміння поняття «збройний конфлікт» члени Комісії тривалий час не могли знайти компроміс стосовно визначення, а саме: яке визначення використовувати - те, що знайшло відображення в резолюції Інституту міжнародного права 1985 р., або дане Трибуналом по колишній Югославії у справі Тадіча. Було використано визначення, вказане в рішенні у справі Тадіча.

У ст. 2 (b) використовується визначення «збройного конфлікту», що міститься в рішенні Міжнародного трибуналу по колишній Югославії у справі Тадіча: «збройний конфлікт існує тоді, коли має місце застосування збройної сили між державами або протягом тривалого періоду відбуваються збройні акти насильства між державною владою і організованими збройними групами або між такими групами всередині держави» ${ }^{8}$. Крім того, слід також зазначити, що багато «громадянських війн» включать в себе «зовнішні елементи», такі як підтримка з боку третіх держав, що постачають зброю, надають навчальні табори та фінансові кошти, які можуть позначитися на характері конфлікту.

Іншим досить спірним моментом постало питання про включення у сферу охоплення проєктами статей ситуацій блокади і окупації, які не супроводжуються застосуванням збройного насильства і військовими діями, що також було вирішено позитивно.

Основний принцип, який закріплюється в Статтях: існування збройного конфлікту ipso facto не припиняє або не призупиняє дію договорів між державами-сторонами цього конфлікту або між державою-стороною збройного конфлікту та державою, яка не є його стороною. Зазначений принцип покликаний сприяти забезпеченню правової стабільності міжнародних відносин. Зокрема, дію цього положення можна проілюструвати практикою договірних відносин між Україною та Росією: факт збройної агресії з боку Російської Федерації per se не призвів до автоматичного припинення договорів між країнами.

У будь-якому разі, коли виникає питання про продовження дії договору у зв'язку зі збройним конфліктом, потрібно встановити, чи містить сам договір положення про продовження його дії. Наприклад, у Міжнародній конвенції щодо запобігання забрудненню моря нафтою 1954 р. говориться: «У разі війни або іншого роду військових дій Договірний уряд <..> може призупинити дію всієї або будь-якої частини цієї Конвенції стосовно всіх або деяких зі своїх територій. Уряд, що припиняє дію Конвенції, має негайно повідомити про це в Бюро» (ст. XIX) ${ }^{9}$. Стаття 89 Конвенції про міжнародну цивільну авіацію 1944 р. передбачає, що «у разі війни положення цієї Конвенції не торкаються свободи дій будь-якої зачепленої війною Договірної держави, як воюючої, так і нейтральної» 10.

Отже, збройний конфлікт у сучасному міжнародному праві ipso facto не припиняє або не призупиняє дію існуючих договорів, незважаючи на те, що низка з них може припинятися або призупинятися з огляду на їх природу, як, наприклад, політичні або торгові угоди.

При вирішенні питання про можливість припинення дії договору, виходу з нього або призупинення його дії у випадку збройного конфлікту необхідно враховувати такі фактори:

a) характер договору - зокрема його предмет, об'єкт і мету, його зміст і кількість сторін договору;

b) характеристики збройного конфлікту - такі як його територіальне поширення, масштаби та інтенсивність, його тривалість i, в разі неміжнародного збройного конфлікту, також ступінь зовнішньої участі (ст. 6).

Фактори, перераховані в підпункті (a), стосуються характеру договору. У підпункті (b) перераховуються чинники, що стосуються характеристик конфлікту, включаючи територіальну сферу охоплення конфлікту, його інтенсивність і тривалість. Наприклад, дія договорів про повітряні перевезення може призупинятися в районах ведення бойових дій, проте має тривати поза зонами бойових дій. Вказівка на «ступінь зовнішньої участі» є релевантною тільки в контексті неміжнародних збройних конфліктів.

Розробники Статей спробували навести орієнтовний (а отже, невичерпний) перелік видів договорів, предмет яких передбачає продовження їх дії. Цей перелік включає:

а) договори про право збройних конфліктів, включаючи документи в галузі міжнародного гуманітарного права;

b) договори, які проголошують, встановлюють або регулюють постійні режими, включаючи угоди, які змінюють сухопутні й морські кордони; 
c) багатосторонні нормовстановлюючі договори;

d) договори про міжнародне кримінальне правосуддя;

е) договори про дружбу, торгівлю і мореплавання і угоди, що стосуються прав приватних осіб;

f) договори про міжнародний захист прав людини;

g) договори, що стосуються міжнародної охорони навколишнього середовища;

h) договори, що стосуються міжнародних водотоків та належних до них споруд і об'єктів;

i) договори, що стосуються водоносних горизонтів та належних до них споруд і об'єктів;

j) установчі акти міжнародних організацій;

k) договори, що стосуються врегулювання міжнародних спорів мирними засобами;

1) договори про дипломатичні та консульські зносини.

Категорії договорів, включені до орієнтовного переліку, викликали велику кількість розбіжностей. Так, знайшли підтримку пропозиції про включення в перелік договорів по грунтовим водам, установчим актам міжнародних організацій, про міжнародне кримінальне переслідування. При цьому було визнано недоцільною пропозицію про виключення деяких категорій з переліку (наприклад, договори про дружбу, торгівлю $і$ мореплавання і аналогічні угоди, що стосуються прав приватних осіб; договори, що стосуються охорони навколишнього середовища; договори, що стосуються міжнародних водотоків та належних до них споруд і об'єктів; договори, що стосуються водоносних горизонтів та належних до них споруд і об'єктів; договори, що стосуються комерційного арбітражу). Крім того, в переліку пропонувалося відобразити договори, що закріплюють норми jus cogens, але Комісія відкинула цю пропозицію. Комісією надано докладні коментарі щодо категорій договорів, що знайшли відображення в переліку. При цьому наголошується, що перелік не $\epsilon$ вичерпним.

Викладене означає, що, незважаючи на військові дії, певні договори зберігають свою силу між воюючими сторонами. За всіх умов зберігають своє значення договори з територіальних питань, насамперед про кордони, які можуть бути переглянуті лише мирним договором. 3 огляду на це, цілком невиправданим було зволікання Україною припинення Договору про дружбу і партнерство між Україною і РФ (дію Договору припинено лише 1 квітня 2019 р.), у ст. 2 якого йшлося про взаємне визнання кордонів країн: «Високі Договірні Сторони відповідно до положень Статуту ООН і зобов'язань по Заключному акту Наради з безпеки і співробітництва в Свропі поважають територіальну цілісність одна одної і підтверджують непорушність існуючих між ними кордонів» ${ }^{11}$.

Часом конвенції передбачають попередні умови, які мають бути виконані сторонами у зв'язку з початком збройного конфлікту. Так, у Віденській конвенції про дипломатичні зносини 1961 р. підкреслюється, що «держава перебування повинна, навіть у випадку збройного конфлікту, надавати сприяння, необхідне для можливо швидкого виїзду осіб, які користуються привілеями та імунітетами...» (ст. 44)12. Зберігають своє значення і починають застосовуватися договори, що стосуються застосування збройних сил. Насамперед це стосується конвенцій гуманітарного права, що встановлюють правила ведення військових дій і норми про захист жертв війни.

Разом із тим, беручи участь у міжнародних і неміжнародних збройних конфліктах, держави не втрачають здатність укладати договори. Відповідно, держави здатні укладати договори під час збройного конфлікту. Вони можуть укладати угоди про перемир'я, угоди про обмін полоненими, а також укладати угоди про припинення або призупинення договорів або договірних норм або вносити в договори поправки або зміни. Так, у Женевській конвенції про захист цивільного населення під час війни 1949 р. говориться: «Коли відповідні сторони доходять згоди стосовно географічного положення нейтралізованої зони, керівництва нею, постачання продуктів харчування до неї та здійснення контролю над нею, представники сторін конфлікту укладають і підписують письмову угоду. Угода встановлює початок і тривалість нейтралізації зони» (ст. 15). «Сторони конфлікту намагаються укладати місцеві угоди про евакуацію з обложених або оточених зон поранених, хворих, інвалідів, осіб похилого віку, дітей і породілей та про пропуск служителів культу всіх віросповідань, медичного персоналу та санітарного майна на їхньому шляху до таких зон» (ст. 17).

Про намір припинити дію договору необхідно повідомити інші держави-сторони або депозитарія договору. Ця вимога випливає зі ст. 65 Віденської конвенції про право міжнародних договорів 1969 р. іє логічним продовженням положення, що існування збройного конфлікту ipso facto не припиняє або не призупиняє дію договорів. Таке повідомлення набуває чинності з дати його отримання іншою державою-стороною або іншими державами-сторонами, якщо воно не передбачає будь-яку іншу дату.

Припинення або призупинення дії договору внаслідок збройного конфлікту жодним чином не зачіпає обов'язок держави виконувати закріплені в договорі зобов'язання, які також існують відповідно до міжнародного права незалежно від цього договору. На таку можливість паралельного існування і застосування договірних та звичаєвих норм міжнародного права звертав увагу О.В. Трояновський ${ }^{13}$. Як зазначив Міжнародний Суд ООН у справі «Нікарагуа проти США», «навіть якщо договірна норма та норма звичаєвого права, що стосується цього спору, мають об'єктивно однаковий зміст, для Суду це не є підставою вважати, що юридична дія цієї договірної норми має в обов'язковому порядку позбавити цю норму звичаєвого права iii самостійного застосування» ${ }^{14}$.

Після припинення збройного конфлікту, якщо сторони не домовилися про інше, відновлення дії призупинених договорів може відбуватися за згодою між відповідними державами.

Висновки. Очевидно, що в міжнародному звичаєвому праві склався певний комплекс норм, що стосуються впливу збройних конфліктів на договори. Збройний конфлікт у сучасному міжнародному праві ipso facto не припиняє або не призупиняє дію існуючих договорів, незважаючи на те, що низка 3 них може припинятися або призупинятися 3 огляду на їх природу. У зв’язку з цим можна говорити, що регулювання дії 
договорів у разі збройного конфлікту націлене на максимально можливе збереження правових відносин між державами.

1 Текст проекта статей о последствиях вооруженных конфликтов для международных договоров. URL: https://legal. un.org/ilc/reports/2011/russian/chp6.pdf

2 Ваттель Э. Право народов или принципы естественного права, применяемые к поведению и делам наций и суверенов / пер. с фр. В.Н. Дурденевского, Ф.А. Кублицкого, Э.М. Фабрикова. Москва: Госюриздат, 1960. С. 526.

3 Хайд Ч.Ч. Международное право, его понимание и применение Соединенными Штатами Америки: в 6 т. / пер. с англ. И.С. Шохор; под ред. [и с примеч.] проф. В.Н. Дурденевского. Москва: Изд-во иностр. лит., 1953. Т. 5. С. 32.

4 Тиунов О.И. Принцип добросовестного соблюдения международных обязательств и действие договоров в случае военного конфликта. Вестник Московского университета. 1979. № 2. С. 29 (Серия 11 «Право»).

5 Віденська конвенція про право міжнародних договорів 1969 p. URL: https://zakon.rada.gov.ua/laws/show/995_118

6 Лукашук И.И. Военные действия и международный договор. Юрист-международник. 2006. № 3. С. 22.

7 Жукорська Я.М. Вплив збройних конфліктів на дію міжнародних договорів. Науковий вісник Міжнародного гуманітарного університету.2014. № 9-1. С. 2014 (Серія «Юриспруденція»).

8 Prosecutor v. Dusko Tadic, IT-94-1-A 72. para. 70. URL: https://www.icty.org/en/case/tadic

9 Международная конвенция по предотвращению загрязнения моря нефтью, 1954 г. URL: https://bellona.ru/2007/05/07/ mezhdunarodnaya-konventsiya-po-predotvr

10 Конвенція про міжнародну цивільну авіацію 1944 p. URL: https://zakon.rada.gov.ua/laws/show/995_038

11 Договір про дружбу, співробітництво і партнерство між Україною і Російською Федерацією, 1997 p. URL: https://zakon. rada.gov.ua/laws/show/643 006

12 Віденська конвенція про дипломатичні зносини 1969 р. URL: https://zakon.rada.gov.ua/laws/show/995_048

13 Трояновский А.В. Современные взгляды на систему источников международного права. Марку Ефимовичу Черкесу - 80: статьи учеников и коллег. Одеса: Фенікс, 2010. С. 106-107.

14 Дело о военной и военизированной деятельности в Никарагуа и против Никарагуа (Никарагуа против США): решение от 27 июня 1986 г. Краткое изложение решений, консультативных заключений и постановлений Международного Суда ООН (1948-1991). Организация Объединенных Наций. Нью-Йорк, 1993. С. 204. URL: http://www.icj-cij.org/homepage/ru/files/sum 1948-1991.pdf

\section{Резюме}

Тєнєшев В.Ф. Вплив збройних конфліктів на дію міжнародних договорів.

Воєнний конфлікт завжди мав серйозний правовий вплив на міжнародні відносини, зокрема договірні зобов'язання. У міжнародному звичаєвому праві склався певний комплекс норм, що стосуються впливу одного з видів воєнних конфліктів збройних конфліктів на договори.

Збройний конфлікт у сучасному міжнародному праві ipso facto не припиняє або не призупиняє дію існуючих договорів, незважаючи на те, що низка 3 них може припинятися або призупинятися з огляду на їх природу. Зазначений принцип покликаний сприяти забезпеченню правової стабільності міжнародних відносин. У зв'язку з цим можна говорити, що регулювання дії договорів у разі збройного конфлікту націлене на максимально можливе збереження правових відносин між державами.

Ключові слова: дія міжнародного договору, збройний конфлікт, порушення договору однією зі сторін, неможливість виконання, докорінна зміна обставин; припинення дії міжнародного договору; призупинення дії міжнародного договору.

\section{Резюме}

\section{Тенешев В.Ф. Влияние вооруженных конфликтов на действие международных договоров.}

Военный конфликт всегда имел серьезный правовое воздействие на международные отношения, в частности договорные обязательства. В международном обычном праве сложился определенный комплекс норм, касающихся влияния одного из видов военных конфликтов - вооруженных конфликтов на договоры.

Вооруженный конфликт в современном международном праве ipso facto не прекращает либо не приостанавливает действие существующих договоров, несмотря на то, что ряд из них может прекращаться или приостанавливаться, учитывая их природу. Указанный принцип призван способствовать обеспечению правовой стабильности международных отношений. В связи с этим можно говорить о том, что регулирование действия договоров в случае вооруженного конфликта нацелено на максимально возможное сохранение правовых отношений между государствами.

Ключевые слова: действие международного договора, вооруженный конфликт, нарушение договора одной из сторон, невозможность исполнения, коренное изменение обстоятельств; прекращение действия международного договора; приостановление действия международного договора.

\section{Summary}

Vyacheslav Teneshev. The impact of armed conflict on the effects of international treaties.

In the science of international law, different views are expressed on the nature of the impact of war on international treaties.

It should also be noted that there is no strict consistency on this issue and in the practice of international relations. This was one of the reasons for the lack of relevant provisions in the Vienna Convention on the Law of Treaties.

Some definite understanding of the content of existing customary norms and trends in the progressive development of international law is given by the Articles of the United Nations Commission on International Law on the Consequences of Armed Conflicts for International Treaties.

The basic principle enshrined in the Articles is that the existence of an armed conflict ipso facto does not terminate or suspend treaties between States Parties to that conflict or between a State Party to an armed conflict and a State which is not a Party to it. This principle is intended to promote the stability of international relations.

The following factors should be considered when deciding whether to terminate, withdraw from, or suspend an armed conflict in the event of an armed conflict: 
a) the nature of the contract - in particular its subject, object and purpose, its content and the number of parties to the contract;

b) The characteristics of an armed conflict, such as its territorial distribution, scale and intensity, its duration and, in the case of a non-international armed conflict, also the degree of external involvement.

The developers of the Articles have tried to provide an indicative (and therefore inexhaustible) list of types of contracts, the subject of which is to extend their validity. The categories of contracts included in the indicative list caused a great deal of disagreement.

The intention to terminate the treaty shall be communicated to the other States Parties or the depository of the treaty. The termination or suspension of a treaty as a result of an armed conflict in no way affects the obligation of the State to fulfill the obligations enshrined in the treaty, which also exist in accordance with international law, regardless of this treaty.

Following the termination of an armed conflict, unless otherwise agreed by the parties, the suspension of the suspended agreements may take place with the agreement of the States concerned.

Obviously, customary international law has developed a set of rules regarding the impact of armed conflict on treaties. Armed conflict in modern international law ipso facto does not terminate or suspend existing treaties, even though a number of them may be terminated or suspended in view of their nature. In this regard, it can be said that the regulation of treaties in the event of armed conflict aims at the maximum possible preservation of legal relations between the states.

Key words: application of an international treaty, armed conflict, violation of a treaty by one of the parties, impossibility of execution, fundamental change of circumstances, termination and suspension of the international treaty. 